\title{
Communication on Social Media in the Covid-19 Vaccination Campaign in Romania
}

\author{
Antonia ENACHE ${ }^{1}$ \\ Marina MILITARU ${ }^{2}$ \\ Diana PANAIT-IONCICA ${ }^{3}$
}

\begin{abstract}
The present study analyses social media discourse in 2021, year two of the Covid-19 pandemic - more specifically, we are tackling appeals made by well-known personalities for people to get the vaccine. For the purpose of our research, we have selected four Romanian Facebook posts, two belonging to politicians in office, one to a young singer and the other one to a well-known actress. By looking into the ways in which these four personalities attempt to convince audiences to follow a certain course of action, we attempt to shed light on how their discourse is structured and how facts and emotion blend in order to convey a compelling message: get the vaccine so as to stop the spread of the lethal virus.
\end{abstract}

Keywords: social media; public discourse; Covid-19 pandemic; vaccination

DOI: 10.24818/DLG/2021/38/04

\section{Introductory remarks and methodology}

7 he present research looks into the way in which the Covid-19 vaccination campaign is being approached in Romania, focusing on the discourse of two main categories of speakers: on the one hand, political speakers, more specifically politicians currently holding power, who tackle the issue from the perspective of someone who has the power to take measures and implement policies. On the other hand, we also analyse the discourse of influencers or the so-called "celebrities", people who do not have the power to do concrete things, but who are perceived as role models by various segments of the public, therefore having the legitimacy

${ }^{1}$ Antonia Enache, Bucharest University of Economic Studies, Romania, antonia.enache@rei.ase.ro

2 Marina Militaru, Bucharest University of Economic Studies, Romania, marina.militaru@rei.ase.ro

${ }^{3}$ Diana Panait-Ioncica, Bucharest University of Economic Studies, Romania, diana.ioncica@rei.ase.ro 
to put forward opinions and arguments likely to impact people's opinions and persuade them to act in the desired manner.

For the purpose of our research, we have selected four Facebook posts from April 2021: two belonging to politicians (one to Klaus Iohannis, the incumbent president of Romania, the other to Nicuşor Dan, the sitting mayor of Bucharest), and two belonging to celebrities: one to Oana Pellea, an acclaimed actress, and one to Irina Rimes, a talented young singer. By comparing the four extracts, we aim to highlight the similarities and differences in the way these four people approach their target audience by resorting to persuasive strategies that use both rational arguments and compelling emotional appeals.

The methodology used largely corresponds to the Critical Discourse Analysis framework, as the research looks into topical social and political issues, issues that are of crucial importance at the present moment. Thus, communication on social media channels is approached in an interdisciplinary manner, touching upon aspects related to linguistics, rhetoric, pragmatics and discourse analysis, while posts are tackled as "a form of social action" (Van Dijk, 2004:353), a way not only of shaping mentalities, but also of directing people towards a specific course of action. Discourse on social media is viewed as a means of persuasion, of strengthening existing bonds and creating new ones.

Since "one of the core goals of political discourse analysis is to seek out ways in which language choice is manipulated for specific political effect" (Wilson, 2004: 410), we have analysed the linguistic choices particular speakers make depending on their public role, as well as the discursive strategies they use when aiming to reinforce the depth of a stringent crisis and to steer the audience towards ways of overcoming it.

In recent years, language on social media has turned into "an interactive activity mediating linguistic and sociocultural knowledge" (Schiffrin, 1998:415), an activity that conveys ideas, gathers together supporters and followers connected by similar mindsets, puts forward possible courses of action and helps towards collecting feedback and upholding a steady relationship with the audience.

There are many aspects to take into account when analysing provaccination discourse and its impact on each speaker's audience, out of which the most important one may be related to the audience themselves. "The term audience is used to describe a number of larger unidentifiable people, all of whom will be using a particular media or receiving a 
particular message" (Lilleker, 2006: 36). Audiences are usually treated as a homogeneous group with similar reactions; however, this could not be farther from the truth. In almost any situation, audiences are made up of individuals with different viewpoints, different perspectives on things and, last but not least, different interests. Therefore, treating audiences as a homogeneous entity relies on an artificially created construct and is therefore likely to lead to breaks in communication.

Never have audiences been more polarized and unpredictable than in the case of the Covid-19 pandemic. Broadly speaking, we can say that what is normally coined as "the general public" has adopted in this case two specific kinds of attitudes.

Firstly, we have those people who are very much afraid of the virus, comply with all regulations, favour tight restrictions (such as social distancing, mask wearing, teleworking and staying indoors as much as possible). For this category of recipients, pro-vaccination discourse finds a fertile soil: not only are they amongst the first to get the vaccine, they also express explicit adherence to the ideas conveyed - on Facebook, adherence to a public speaker's belief can easily be monitored by counting the number of likes a post receives.

Secondly, we find people situated at the opposite end of the belief spectrum, the supporters of the so-called "coronaskeptic movement". For this part of the audience, pro-vaccination discourse is annoying - they strongly believe that the restrictions represent violations of fundamental rights and liberties and that advertising for medication is unethical, not to mention some viewpoints that call for compulsory vaccination, since they strongly feel that every person ought to be free to choose whether they want to get the vaccine or not. This part of the audience is not likely to respond positively to the campaign; by contrast, they may post comments expressing disagreement or simply ignore the campaign.

As is normally the case with any opinion trend that polarizes public opinion, there would normally exist a third category of people, the indifferents. This category would include people who are not aware of or interested in a certain social issue and would therefore have very little to no response to any attempt to make them adhere to a cause. However, in this particular case, given the magnitude of the Covid-19 crisis and the way in which it has impacted everyone's lives in unprecedented ways, we could safely assume that the indifferents are very few, if at all. Moreover, given the blatant incompatibility between the views of the two main categories of 
people responding to the campaign, we can safely assume that provaccination discourse targets primarily people who already intended to get the shot in the first place, as we mentally adhere to theories that correspond to our pre-existing beliefs. "Every opinion is a marriage of information and predisposition: information to form a mental picture of the given issues, and predisposition to motivate some conclusion about it (Helfert, 2018: 73). Our response to someone's persuasive actions relies to a great extent upon "information already assimilated and opinions already held" (Helfert, 2018: 73); therefore, the more audiences feel the same as the message communicator about a certain subject, the more likely they are to be influenced; hence, the urge to get the vaccine will resonate primarily with those who intended to get it anyway, even before reading that message.

\section{A few remarks on the importance of social media in public communication}

The internet in general, and social media in particular, represent the most recent tools of communication and offer a wide range of opportunities for targeted messages to reach specific audiences who are likely to respond in the manner desired by the initiator. Gainous and Wagner define social media as "a broad and growing portion of the internet that is designed as a platform which allows users, and groups of users to create and exchange content, often in an interactive or collaborative fashion." (Gainous and Wagner, 2013: 2). Indeed, the unprecedented advent of social media has resulted in a shift in how communication unfolds in the public space, in two fundamental ways: on the one hand, they provide immediacy, convenience and affordability - a message can reach audiences instantly, irrespective of time and place considerations. On the other hand, the increased interactivity of this means of communication, whereby anyone can provide feedback, either positive or negative, gives a public speaker a fair enough perspective on how the public stands on a certain issue, while also enabling them to act accordingly in the future.

Most aspects of our lives today are mediated by digital technology, while "social media is truly democratized communication" (Helfert, 2018: 199). Out of all the existing platforms, "Facebook is by far the most heavily used social media platform, claiming 1.35 billion active user per month and 864 per day" (Helfert, 2018: 200); it is also a very complex, comprehensive platform, allowing users to post detailed messages, long texts, photos and 
videos and to interact publicly. Overall, Facebook appears to be an environment which prompts anyone to disseminate messages and start conversations, allows for extensive interaction, contributes to building name recognition, to the "branding" (Lilleker, 2006: 41) of celebrities and to a rapid increase in visibility and in the number of followers.

However, social media is clearly not a place where a public figure can relax. Although, at least in theory, this type of communication spawns familiarity and allows for the connection between people who think alike, in reality, negative feedback is a frequent occurrence initiators must deal with. Social media facilitate the telling of stories that meet the essential condition of "newsworthiness" - namely, information that has a certain news value, that can be said to count and that is centred around the parameters of timeliness, proximity and prominence (Jones, Jaworska and Aslan, 2021: 31); they help create "an ongoing sense of presence between the speaker and the audience" (Jones, Jaworska and Aslan, 2021: 31), while at the same time implying a high degree of exposure for the speaker. In other words, increased interactivity cannot be separated from increased vulnerability - both to the inadvertent revelation of one's weaknesses, and to extraneous negativity and even aggression.

\section{The discourse of officials}

The Covid-19 pandemic has had a shattering effect on people's lives, leading to a major shift in the way we interpret reality. It has challenged the social, economic and political environment across the board, requiring new, quick and possibly controversial solutions. Politicians worldwide found themselves facing new responsibilities overnight; thus, they were compelled to use all resources to fight the social and economic consequences of the outbreak, while at the same time striving to keep people's morale at an acceptable level and to make them see the end of the tunnel. With much to lose in terms of face, image and reputation, political actors have had to take measures that risked seriously jeopardizing their popularity. Therefore, the clash between the new political reality (resulting in renewed challenges and obligations) and the need to maintain the support of their voters has had a profound influence on the way politicians have communicated with audiences. 
Throughout the pandemic, most mainstream discourse has been replete with emotional appeals and urges for audiences to act selflessly so as to stop the spread of the pandemic and protect other people, especially vulnerable ones, from catching the potentially lethal virus. However, in the case of political actors, that is, of people whose role includes access to power and therefore, the ability to do something to improve the situation, emotion is not enough. People worldwide expect politicians to do things, to take measures and implement policies in order to put an end to the ordeal. Therefore, we often notice discourse that is rational, fact-focused, futureoriented and, in some cases, emotion-free. In the current section of our research, we shall focus on two such examples and show how politicians attempt to persuade audiences to get the vaccine by referring to concrete measures that have been taken.

\section{Ex. 1. Klaus Iohannis:}

(a) Există o singură cale de ieșire din pandemie și aceasta este vaccinarea!

(b) Restricțiile nu înlătură, ci doar încetinesc răspândirea virusului.

(c) Din păcate, suntem în continuare în plină pandemie și doar vaccinarea ne permite ca la vară să plecăm unde dorim în concediu, să mergem la concerte ori la teatru.

(d) Putem să ne gândim la eliminarea graduală a unor restricții, dacă vom continua imunizarea într-un ritm susținut, mai ales că avem tot mai multe tipuri de vaccin la dispoziție.

(e) Astăzi am vizitat primul centru de vaccinare mobil în funcțiune, în județul Ilfov.

(f) Se vor deschide și alte astfel de centre, unde oamenii pot merge fără programare și vom găsi noi modalități de a-i ajuta pe cei care doresc să se vaccineze.

(a) There is only one way out of the pandemic, and that is vaccination!

(b) Restrictions do not eliminate the virus, their only slow down its spreading.

(c) Unfortunately, we are still in the midst of the pandemic and vaccination alone will allow us to go on holiday wherever we want in the summer, to go to concerts or to the theatre.

(d) We can consider the gradual elimination of some restrictions, if we continue immunization at a steady pace, especially since we have an ever wider range of vaccines at our disposal.

(e) Today, I have visited the first mobile vaccination centre that is up and running in Ilfov County. 
(f) Other such centres will open where people can go without an appointment, and we shall find new ways to help those who wish to get vaccinated. (Facebook, April 21, 20214)

As we have stated above, official pro-vaccination discourse is inherently fact-focused. Even when politicians insert emotional appeals into their persuasive strategies, facts are in most cases at the forefront. As we have said, the explanation is simple: politicians holding power are decision-makers; hence, their primary role is to solve the crisis at hand, and only then to communicate with audiences and let them know what has been done already and what will be done in the future. Since they have the power to implement measures that will benefit the population, appealing to emotion in the absence of any such measures or of any mention thereof would cast the political actor in a bad light and make them lose credibility. By contrast, reference to things that have been done bestows legitimacy on political actors, contributes to their permanent campaigning - "the use of office by elected individuals (...) to build and maintain popular support" (Lilleker, 2006:143) and makes them look good in the eyes of past and possibly future electors.

Extract (1) puts forward a compelling appeal, whereby the only way out of the pandemic is for people to get the vaccine. The rhetor invokes the restrictions, whose impact on people's social and economic well-being has been devastating, only to highlight that they were just a part of the solution to the problem, whereas the ultimate and certain way out is the vaccine. Thus, the extract above is structured as follows: Sentence (a) summarizes the essence of the politician's discourse, namely the fact that vaccination is the only way out of the pandemic. This statement is very much in line with the discourse of other public figures (politicians, but also celebrities and other types of influencers) as well as with the message of the mainstream media. Repetition is of the essence in ensuring the general impact of a message (Domenach, 2004: 76), and in many cases the constant repetition of a few general ideas exempts the speaker from providing rational arguments to back their views. In this case, the use of the exclamation mark, the written equivalent of an emotional outburst, also helps towards enhancing the powerful impact of the message.

${ }^{4}$ https://www.facebook.com/klausiohannis, accessed on May 21, 2021 
Subsequently, the stretch of discourse is broken into tiny sequences, each carrying its own persuasive force. While resorting to a rational argument, statement (b) equally aims to tap into the public's negative emotion of fear - despite the severe restrictions that have made life a nightmare for too many for too long, they are not the way out. We are still at risk, danger still looms. Resorting to fear continues with statement (c), where the speaker subsumes the ideas in both (a) and (b): the fact that vaccination is the only solution, alongside an appeal to the audience's fears; however, this time he elaborates on the solution by referring to some concrete means of entertainment that everyone has missed: carefree holidays, concerts or theatres. Thus, we can see that statements (a), (b) and (c) together make up the former half of the discourse - the rhetor uses strategies similar to those employed in advertising, such as alternating reference to problem and solution, emotional appeals and the promise of a future reward that is worth the necessary sacrifice.

In its turn, statement $(d)$ reinforces the ideas expressed up until this point: vaccination this time is envisioned as a condition for the gradual elimination of restrictions - we are looking at the "carrot and stick" tactic, whereby the promise of the future reward is boosted by one further incentive: the wide range of vaccines one can choose from. By contrast, the last two parts of the extracts, (e) and (f), shift the focus of discourse from the audience to the speaker himself. If so far, the discourse has revolved around the actions expected from the public (to get the vaccine) and the promises made to them (the elimination of restrictions), here the orator changes the persuasive approach by invoking his personal example: from statement (e), two main ideas emerge. Firstly, the political speaker wants us to become aware of the existence of a certain vaccination centre, the one in Ilfov - this is the concrete action of raising awareness. Secondly, he is intent on us finding out about his own personal example, about his own actions: not only does the centre mentioned exist and is available to all, but the president himself has visited the location. Thus, by blending a rational approach with the inspirational personal example, the speaker conveys an impression of involvement, participation, civic activism and social responsibility - all values meant to motivate the audience and propel them towards the desired action.

Lastly, statement (f) conveys a new promise made to the public, that more vaccination centres will open and thus everyone willing will have unrestricted access to the jab. If we look back on the extract in its entirety, 
we notice several characteristics of the way in which the issue is tackled overall. Firstly, there is a marked passage from sentiment to reason, from tapping into our negative emotion of fear towards dissipating those very fears into the promise of a brighter, covid-free future. Secondly, the speaker aims to cast himself as a pro-active, involved political actor who not only gets things done by others, but also becomes involved in the struggle with the pandemic himself. And thirdly, since Iohannis is the president of Romania and immense responsibility falls upon him, his discourse is both inspirational (urging and motivating others towards a certain course of action) and proactive (fact-focused, showing everyone that he is at the core of the problem, striving to solve it).

\section{Ex. 2. Nicusor Dan:}

In această dimineață a fost deschis centrul de vaccinare anti-COVID-19 din Piața Constituției, primul centru de vaccinare drive-thru din București. Vaccinarea a început la ora 8, iar până acum, în primele 2 ore, au fost vaccinate deja 100 de persoane.

Mă bucur că președintele României, Klaus Iohannis, a răspuns invitației Primăriei Capitalei de a fi prezent la această inaugurare, susținând astfel popularizarea acestei soluții extrem de accesibile pentru vaccinarea bucureștenilor.

Indemn cu această ocazie oamenii să vină să se vaccineze la noul centru de vaccinare: fără programare și direct din mașină. (Facebook, April 29, 20215)

This morning, the anti-Covid vaccination centre in Constituției Square has opened, the first drive-thru vaccination centre in Bucharest. Vaccination started at 8 AM and so far, in the first two hours, 100 people have already received the vaccine.

I am delighted that the President of Romania, Klaus Iohannis, has answered the invitation of the Bucharest City Hall to attend this launch, thus supporting the popularization of this hugely convenient solution for vaccinating the citizens of Bucharest.

I use this opportunity to invite people to come and get the vaccine at the new centre: without any appointment, straight from the car.

The discourse of the Mayor of Bucharest is almost exclusively rational, detached and fact-focused. The speaker starts his Facebook post

${ }^{5}$ https://www.facebook.com/NicusorDan.ro, accessed on May 23, 2021. 
by referring to a concrete fact: the recent opening of a vaccination centre that is also a drive-through. In this section, we notice a multi-purpose approach: firstly, by explaining what has been done, the political actor attempts to cast himself as a person involved in the fight with the pandemic, a person who aims to bring the solution closer to the population. Secondly, the mentioned centre meets three conditions at the same time: availability, immediacy and convenience, all of which are of paramount importance in a world that is increasingly on the run, striving to meet deadlines and to make the most of every second available. Thirdly, the speaker is intent on legitimizing his actions by informing the audience that a significant number of people have already reacted in the desired manner and implicitly inviting others to follow suit. Regarding this aspect, we could also safely assume that, by highlighting other people's enthusiasm with the new centre, the mayor also aims to trigger in his readers the sense of belonging to a community that will benefit all of its members.

Increased legitimacy is also sought by reference to the president of Romania. His presence bestows credibility on the Mayor's actions and is likely to boost people's enthusiasm. The more publicity an event of this magnitude receives, the better; in this case, the support of the Head of State conveys the message that the launch is hugely important, supported by officials of the highest rank, and is being popularized in every way possible. Finally, at the end of the extract, the speaker openly and explicitly urges people to use the services of the new vaccination centre, once more reiterating the availability and convenience of the location.

Given the controversial nature of the Covid-19 vaccines, the worldwide protests against the policy of enforcing the vaccine as a condition for access to travelling, cultural events or other popular activities, the strategy of providing incentives to those willing to get the shot appears to be the most efficient and trouble-free solution. Broadly speaking, the "carrot and stick" strategy can be defined as a means of alternating reward and punishment in order to get the recipient of the message to follow a certain course of action desired by the initiator. Since a vaccine is a form of medical treatment that is one hundred percent dependent on the consent of the subject, hence making punishments unethical, motivating the audience by offering incentives (thus focusing on positive rather than negative motivation) is the strategy that works best and also the safest from all points of view. Not only are punishments of any kind discriminatory and therefore illegal; also, positive motivation is known to work better than 
negative motivation, as it is based on consent instead of coercion, it taps into our emotional resources of hope rather than fear, and is known to encourage cooperation and spawn a feeling of mutual trust between the parties involved.

\section{The discourse of celebrities}

Unlike political actors, celebrities (actors, singers, social media influencers) do not wield political power, nor can they implement policies affecting citizens' lives. Therefore, in their persuasive appeals, celebrities resort to a set of strategies different from those used by politicians. Firstly, since they represent role modes for different social categories, their appeals are mainly emotional, inspirational, relying on the force of their personal example, on personal belief and on establishing a connection with the audience, connection that will propel message recipients to follow suit due to the way our brains are wired, messages incorporating emotional elements are more likely to have an impact than those based strictly on reason (Helfert, 2018: 75-76).

Emotional connection is easily established through storytelling, "an essential part of the transfer of values and traditions in cultures throughout history" (Helfert, 2018: 69), while narratives can be extremely effective in promoting ideas. Storytelling is usually imbued with glimpses of personal disclosures, the message communicator reveals themselves as a human being, spawning a feeling of friendliness and intimacy with the audience. Last but not least, through storytelling on social media, a "performance" dimension is attached, bestowing further legitimacy on the communicator and increasing the efficiency of the message. To reach adherence to one's ideas, nothing works better than the contagion of the human example, with its aura of personal contact and commitment. (Domenach, 2004: 88)

\section{Ex. 3. Irina Rimes:}

M-am vaccinat. Nu m-a pus nimeni, nu m-a plătit nimeni sa vorbesc despre asta și nu reprezint interesele nimănui. Reprezint interesele mele personale, pur egoiste. M-am vaccinat pentru ca NU MAI POT FĂR $\breve{A}$ CONCERTE, m-am vaccinat pentru ca vreau sa ma întorc pe scena. M-am vaccinat pentru ca vreau sa revenim la normal cât mai curând posibil. Mi-e dor de NORMAL.

I got the vaccine. No one made me, no one paid me to speak about it and I don't represent anyone's interests. I represent my own, purely selfish personal interests. 
I got the vaccine because I CAN'T TAKE A LIFE WITHOUT CONCERTS ANYMORE, I got the vaccine because I want to return on stage. I got the vaccine because I want us to return to normal as soon as possible. I miss NORMAL. (Facebook, April 30, 2021) ${ }^{6}$.

The extract above represents a break from standard pro-vaccination discourse, which is focused on the concepts of responsibility, of selflessness, of submitting to the general good in order to protect other (more vulnerable) people from the deadly virus. Ever since the outbreak of the pandemic, public discourse has focused on protecting others - at the beginning, through the overpowering appeal "Stay home - it could save lives" and later, through appeals to get the vaccine in order not to spread the virus. We can rightfully say that the shift in approach was intentional, since the public has been overwhelmed with urges revolving around the idea of sacrifice; against this background, a discourse centred on the self is more likely to be noticed and remembered, not to mention a welcome breath of fresh air. In the above, the speaker highlights the following ideas:

- the fact that she has received the vaccine herself, thus aiming to persuade through the force of her personal example;

- the fact that she has done so out of her own accord and is not paid to advocate the cause - hence, the speaker comes across as sincere, she is credible and her approach gains legitimacy;

- the fact that she has decided to get the vaccine out of selfishness - here, we have the climax of the extract, the point where the Facebook post detaches itself from mainstream discourse and stands out through emphasis on the self rather than on the other. The singer feels it is important to underline that it is for her own personal good that she has made this choice; in so doing, she provides yet another proof of her sincerity and casts herself off as an authentic public figure. Authenticity is a crucial concept in communication, as public figures who develop an authentic image will "present themselves as being more emotional" (Lilleker, 2006: 40), as real people with real feelings that audiences can identify themselves with. Authenticity bestows an aura of credibility on the public speaker and makes audiences trust them and relate to them on a more personal level.

${ }^{6}$ https://www.facebook.com/IrinaRimesOficial, accessed on May 9, 2021.

Dialogos • Vol. XXII No. 38/2021 
Paradoxically, the very fact that the speaker explicitly attempts to present herself as a selfish person results in the opposite effect: she will be perceived as an honest, truthful person, with normal desires that the public deeply relates to. The speaker invokes her strong wish to return to singing live, thus appealing to many people's desire to resume work in a "live" context, one involving physical presence and interaction with others rather than the coldness of a screen. She stresses the idea that she is at the end of her rope and that her strongest wish is to return to normalcy - in this context, she does not explicitly state, but we can infer, that the only way to reinstate normalcy would be for as many people as possible to get the vaccine - in this respect, a powerful persuasive streak stems precisely from what is not stated, but implied - that the vaccine is the fastest way back to what we used to consider "normal".

Undoubtedly, it is important to specify that Irina Rimes is a wellliked celebrity, that she stands out in a crowd of singers of all ages due to her musical talent, originality and charisma. Against a background of wannabe singers of questionable talent, hers is beyond any doubt. In February 2020 she was appointed a cultural ambassador for the Constantin Brâncuși celebration, a nomination which, albeit controversial, was generally considered appropriate due to the influence this singer has on younger generations and on her ability to popularize a sculptor that would otherwise appeal only to the cultural and academic elites. What is significant about this singer is that she combines a remarkable musical background and real talent with the ability to relate to young people - thus, in a world of imposture and artifice, she is considered to be "the real deal". Therefore, we can safely assume that her message is likely to visibly impact social media users, especially younger ones, and to persuade them to get the vaccine.

\section{Ex. 4. Oana Pellea:}

"În primul rând, mă pot vaccina, ceea ce am făcut. Am făcut și rapelul deja. Am făcut asta dintr-un respect față de mine, o datorie față de mine și față de comunitate. Actorii sunt foarte văduviți. Am fost un an și atâtea luni puși deoparte, nu am avut bucuria împărtășirii artei noastre cu publicul și asta a fost dureros. Pe de altă parte, sunt actori independenți care chiar nu au mai putut sŭ-și câștige pâinea cea de toate zilele. Deci situația e dramatică".

First of all, I am able to get the vaccine, which I did. I already had the second jab. I did this out of respect for myself, out of a duty to myself and to the community. 
Actors have been deeply affected. We have been isolated for a year and so many months, we have been deprived of the joy of sharing our art with the public and that has been painful. On the other hand, there are independent actors who have really been unable to earn their daily bread. Therefore, the situation is dramatic" (Facebook, April 28, 20217 - extract from an interview with RFI').

Oana Pellea's discourse resorts to a wider range of persuasive strategies than Irina Rimes'. While she begins in the same way, by stating that she has received the vaccine (both jabs), she highlights the fact that at the basis of her decision lies not only a duty to herself, but also a duty to the community. Thus, her discourse appears to be very much in line with the general approach promoted by the media, that we must get vaccinated in order to submit to the general good. If general public discourse aiming to persuade people to receive the desired treatment could be summarized in one word, that word would be selflessness. In this respect, Oana Pellea does not deviate from the norm. She does, however, add a personal touch to it by inserting reference to the self and to the larger professional group she belongs to.

In its turn, the invocation of the problems actors are facing follows a two-fold path. In describing their hardship, Pellea begins with a general statement: "Actors have been deeply affected", which she subsequently enlarges upon by providing details. Hence, we learn that, firstly, actors have been deprived of the joy of sharing their art with the public and have suffered as a consequence of this. Secondly, she turns to independent actors (freelancers) who have been in an even direr situation, they have been unable to make a living throughout the pandemic, as they have not been allowed to work. Through this reverse Maslow's pyramid, where the speaker first invokes spiritual, personal growth-related needs (such as the need to share your art), and only then moves into the realm of the concrete by referring to the immediate need to earn a living, Pellea reaches two discursive purposes. On the one hand, by presenting things in this order, she conveys the implicit message that for an artist, for a culture creator, spiritual joys come before and overpower concrete, immediate well-being.

\footnotetext{
${ }^{7}$ https://www.facebook.com/oana.pellea, accessed on May 24, 2021

${ }^{8}$ https://m.rfi.ro/cultura-133427-oana-pellea-vaccinatcovid?fbclid=IwAR2w1FM278BZOr1uDJ94b6vCJf1Zwi5wWHRPqO8R5I0gMtj1X

DikzpcER40, accessed on May 24.2021
} 
On the other hand, and equally importantly, the reverse order gives her a chance to end this part of her interview on a dramatic note and makes the entire extract more powerful, more compelling, more likely to trigger an emotional response in the audience.

The fact that the information placed at the end of a stretch of discourse is best remembered and most impactful is well-known. Since Oana Pellea stands out as a well-accomplished actress, while in the pandemic she reinvented herself as a teacher of communication skills ${ }^{9}$, we believe we are not mistaken in assuming that the order in which she conveys the information is not accidental, but intentional - in this way, she can achieve the desired effect in a better way and make sure the hardships faced by actors are known to and understood by the public.

Last but not least, we must remember that Oana Pellea's target audience can broadly be described as the intelligentsia, the cultural elites of the Romanian society. The power of her personal example is likely to impact the mentalities and attitudes of a social category different from Irina Rimes' followers. Every public persona who enjoys a positive image and has followers on social media directs their messages at groups characterized by similar social, economic and political situations. “(...) Consumers of information select content that agrees with their beliefs, attitudes, and values, thus avoiding conflicting information or ideas." (Denton, Trent and Friedenberg, 2022: 340) These people are linked and communicate via social networks and have similar cultural orientations, similar interests, lifestyles and convictions, and are likely to respond to similar messages. Though we have witnessed in recent years a convergence of previously different social castes due to the advent of "popular culture" (Lilleker, 2006: 157), boundaries still exist and every influencer generally attempts to resonate with the prevalent mindset and assumptions of the caste they identify themselves with.

\section{Conclusions}

In the present research, we have attempted to shed light on how communication on social media works in times of crisis and turmoil - more specifically, we have focused on attempts made by well-known

\footnotetext{
${ }^{9} \mathrm{https} / / /$ oanapellea.cartilepefata.ro/courses/masterclass-de-comunicare-i-vorbit-inpublic-cu-oana-pellea, accessed on May 29, 2021
} 
personalities to convince audiences to receive the Covid-19 vaccine. We have analysed the discourse of incumbent officials alongside the discourse of celebrities, emphasizing the way they communicate with their social media followers in order to persuade them to pursue a certain course of action. We have taken into account the way they structure their discourse by blending storytelling, the mentioning of facts and emotional appeals to increase the compelling power of their message. We have also shown how, while the discourse of officials usually includes a summary of what they have accomplished already as well as what they intend to do, so as to gain credibility and prove participation in crisis solving, the discourse of celebrities relies to a larger extent on emotional appeals, on the force of their personal example and on bonding with the audiences on a more personal level.

Based on our research and on the extracts analysed, we can safely say that, while communication on social media plays a powerful role in the lives of both politicians and entertainers, civic participation, which is what they all pursue in the selected posts, is compulsory for politicians, an inherent segment of their activity, while for celebrities it is optional; still, despite the risks attached to any opinion publicly expressed, such as antagonizing a part of the audience, civic participation through communication on social media channels has more advantages than disadvantages, as it enables public figures to come across as people similar to their audience, to bond and interact with the latter, to convey an impression of authenticity, honesty and trustworthiness and to strengthen the support of followers with similar mindsets.

\section{References and bibliography}

1. CHILTON, Paul (2006), Analysing Political Discourse, Theory and Practice, Routledge, London

2. DENTON Jr., Robert E., TRENT, Judith, and FRIEDENBERG, Robert V. (2020), Political Campaign Communication, Rowman \& Littlefield, Lanham

3. Van DIJK, Teun A. (2004), "Critical Discourse Analysis", in SCHIFFRIN, Deborah, TANNEN, Deborah and HAMILTON, Heidi E. (eds.), The Handbook of Discourse Analysis, Oxford: Blackwell, Oxford 
4. DOMENACH, Jean-Marie (2004), Propaganda politică, Institutul European, Iași

5. GAINOUS, Jason and Wagner, Kevin M. (2013), Tweeting to Power: The Social Media Revolution in American Politics, Oxford Scholarship Online

6. GERSTLE, Jacques (2002), Comunicarea politică, Institutul European, Iași

7. HELFERT, David L. (2018), Political Communication in Action From Theory to Practice, Lynne Rienner Publishers, London

8. JONES, Rodney H., JAWORSKA, Sylvia, and ASLAN, Erhan (2021), Language and Media, A Resource Book for Students, Routledge, London

9. LILLEKER, Darren G. (2006), Key Concepts in Political Communication, Sage Publications, London

10. LILLEKER, Darren, COMAN, Ioana A., GREGOR, Miloš and NOVELLI, Edoardo (eds., 2021), Political Communication and Covid19, Governance and Rhetoric in Times of Crisis, Routledge, London

11. SCHIFFRIN, Deborah (1998), Approaches to Discourse, Blackwell, Oxford

12. WILSON, John (2004), Political Discourse, in in SCHIFFRIN, Deborah, TANNEN, Deborah and HAMILTON, Heidi E. (eds.), The Handbook of Discourse Analysis, Oxford: Blackwell, Oxford

13. YULE, George (2020), The Study of Language, CUP, Cambridge 